\title{
Decreased beta-cell mass in diabetes: significance, mechanisms and therapeutic implications
}

\author{
M. Y. Donath ${ }^{1}$ • P. A. Halban ${ }^{2}$ \\ ${ }^{1}$ Division of Endocrinology and Diabetes, Department of Medicine, University Hospital, Zurich, Switzerland \\ 2 Department of Genetic Medicine and Development, University Medical Centre, Geneva, Switzerland
}

\begin{abstract}
Increasing evidence indicates that decreased functional beta-cell mass is the hallmark of both Type 1 and Type 2 diabetes. This underlies the absolute or relative insulin insufficiency in both conditions. In this For Debate, we consider the possible mechanisms responsible for beta-cell death and impaired function and their relative contribution to insulin insufficiency in diabetes. Betacell apoptosis and impaired proliferation consequent to
\end{abstract}

hyperglycaemia is one pathway that could be operating in all forms of diabetes. Autoimmunity and other routes to beta-cell death are also considered. Recognition of decreased functional beta-cell mass and its overlapping multifactorial aetiology in diabetic states, leads us to propose a unifying classification of diabetes. [Diabetologia (2004) 47:581-589]

Keywords Hyperglycaemia - Apoptosis . Proliferation $\cdot$ Cytokines $\cdot$ Insulin
Type 1 diabetes is recognised as a condition of absolute insulin deficiency due to destruction of beta cells. To the extent that this aetiology is not in dispute, it will not be a major focus of this For Debate. By contrast, Type 2 diabetes was for many years attributed solely to insulin resistance. Although altered insulin secretion in patients with Type 2 diabetes had already been demonstrated in the 1960's $[1,2,3]$, it was not until the 1980's that the debate on the true aetiology of the disease became heated. Thus, once the reality of impaired betacell function in Type 2 diabetes was acknowledged even by the most fervent champions of insulin resistance [4], this debate focused in the first instance on the relative importance of these two components and their putative respective causality. There is now general agreement that all hypotheses were correct to a certain

Received: 18 September 2003 / Revised: 17 December 2003

Published online: 7 February 2004

(C) Springer-Verlag 2004

M. Y. Donath (

Division of Endocrinology and Diabetes,

Department of Medicine, University Hospital,

8091 Zurich, Switzerland

E-mail: marc.donath@usz.ch degree and that Type 2 diabetes is a complex pathophysiologic spectrum encompassing situations reflecting the combination of beta-cell failure or demise and insulin resistance to varying degrees. More recently, the debate has been complicated by equally heated discussion on the cause of impaired insulin secretion: is this due to reduced beta-cell mass or to an intrinsic defect in the secretory machinery of the beta-cells or both? Now that the significant reduction in beta-cell mass observed many years ago $[5,6]$ has been clearly established in Type 2 diabetes [7, 8, 9], studies must focus on whether such a reduction alone can account for impaired insulin secretion and on the molecular mechanism responsible for the decreased beta-cell mass.

\section{Insufficient insulin secretion in Type 2 diabetes}

The defect in insulin secretion in Type 2 diabetes is the consequence of two confounding components: insulin deficiency and disturbed kinetics of secretion combined with impaired glucose stimulus-secretion coupling.

Insulin deficiency. It cannot be stressed enough that insulin deficiency in Type 2 diabetes is relative to the 
prevailing hyperglycaemia and reflects the analytical methods used. The simple measurement of circulating concentrations of immunoreactive insulin at least at early stages of the disease, shows hyperinsulinaemia. Clearly, however, this level of immunoreactive insulin is insufficient to control the prevailing hyperglycaemia: hence "insulin deficiency". Most conventional assays detect both proinsulin and insulin indifferently. Yet, it has been known for some time that Type 2 diabetes is characterised by an increased ratio of proinsulin:insulin $[10,11]$ and that the biological activity of proinsulin is approximately $10 \%$ that of fullyprocessed insulin. Thus, in order to assess the hypoglycaemic potential of circulating insulin, one should in reality consider only the true insulin component rather than total immunoreactivity (reflecting all immunoreactive species including proinsulin and conversion intermediates). When this is done, the insulin deficiency becomes more evident. In addition, most measurements are done on a single fasting blood sample, yet it is under these conditions that the demand for insulin is at its lowest. Only after stimulation does the magnitude of the insulin deficiency become fully manifest. Leaving aside the specific defect in glucose stimulation, even a potent stimulus such as arginine elicits a markedly diminished insulin response in patients with Type 2 diabetes [12]. Thus, we have shown that after an i.v. arginine challenge, patients with Type 2 diabetes and with a high fasting concentration of immunoreactive insulin (163\% of the control subjects) only released $62 \%$ as much immunoreactive insulin as the control subjects [11].

Beta-cell secretory defect. Insulin secretion from subjects with Type 2 diabetes is characterised by a relatively selective loss of glucose stimulation manifested by the lack of first phase of secretion and decreased second phase. Sensitivity to non-metabolisable stimuli such as arginine remains normal although the magnitude of the response may be attenuated. Baseline insulin secretion is normally pulsatile, with a periodicity of 5 to $10 \mathrm{~min}$. Such pulsatility of insulin secretion, believed to be important for normal glucose homeostasis, is also perturbed in Type 2 diabetes as are the ultradian oscillations of insulin secretion [13, 14]. This could in addition, at least in part, account for some insulin resistance $[15,16,17]$. These defects in secretion, and particularly the lack of response towards glucose, act in concert with the insulin deficiency along with a disproportionate amount of proinsulin. Together, they compromise severely the ability of residual beta cells to provide sufficient insulin to achieve euglycaemia in the face of insulin resistance. When evaluated during an OGTT, these secretory defects can be observed shortly after glucose ingestion.

\section{Decreased beta-cell mass in Type 2 diabetes}

It was suggested many years ago that beta-cell mass is reduced in Type 2 diabetes ([18] and see [19] for a more recent review). This decrease in beta-cell mass has been confirmed by a series of convincing studies in which beta-cell mass was quantified morphometrically in a large series of pancreata from patients with Type 2 diabetes and appropriately matched control subjects $[7,8,9]$. Thus, and most importantly, obese patients with Type 2 diabetes have decreased beta-cell mass compared to obese individuals without diabetes. This suggests that in patients with Type 2 diabetes there is a loss of beta cells and/or impaired augmentation of beta-cell mass consequent to increased demand. By contrast, the beta-cell mass in non-obese control subjects was not significantly different to that of obese patients with Type 2 diabetes. This could explain the discrepancies in earlier studies. By definition, any change in beta-cell mass must reflect an altered balance between the rate of production (whether by neogenesis or replication of beta cells) and disappearance (cell death by necrosis or apoptosis). It is difficult to distinguish between the two mechanisms in human tissue sections mainly because dead cells are removed rapidly from the islet by macrophages and neighbouring cells, making it hard to quantify cell death. Although cell proliferation can be quantified in tissue sections using markers such as Ki-67, this only provides a single snapshot in time which probably does not reflect accurately the complex dynamic of the process. Nevertheless, one study in humans does indicate that increased apoptosis is of greater importance in the reduced beta-cell mass of Type 2 diabetes than impaired neogenesis and/or proliferation [8]. It is important to note that these studies in humans cannot be prospective in nature, given that they were done at autopsy. Most specifically, the beta-cell mass in these individuals before onset of the disease is not known. Thus individuals susceptible to diabetes possibly have limited beta-cell mass early in life, perhaps even at birth, due to genetic or environmental factors. If such were the case, the decrease in beta-cell mass seen in patients with Type 2 diabetes would not necessarily be the sole consequence of the disease itself.

\section{Mechanism of beta-cell death in Type 2 diabetes}

Major mechanisms proposed to lead to beta-cell death in Type 2 diabetes and discussed here include: increased circulating cell nutrients, ER-stress, signalling factors from the adipocyte, and iatrogenic mechanisms. This For Debate is obviously not all-inclusive. Without any prejudice towards the other mechanisms and their relative importance, as well as the valuable contributions of the respective authors, we focus primarily on the pro-apoptotic effect of hyperglycaemia 


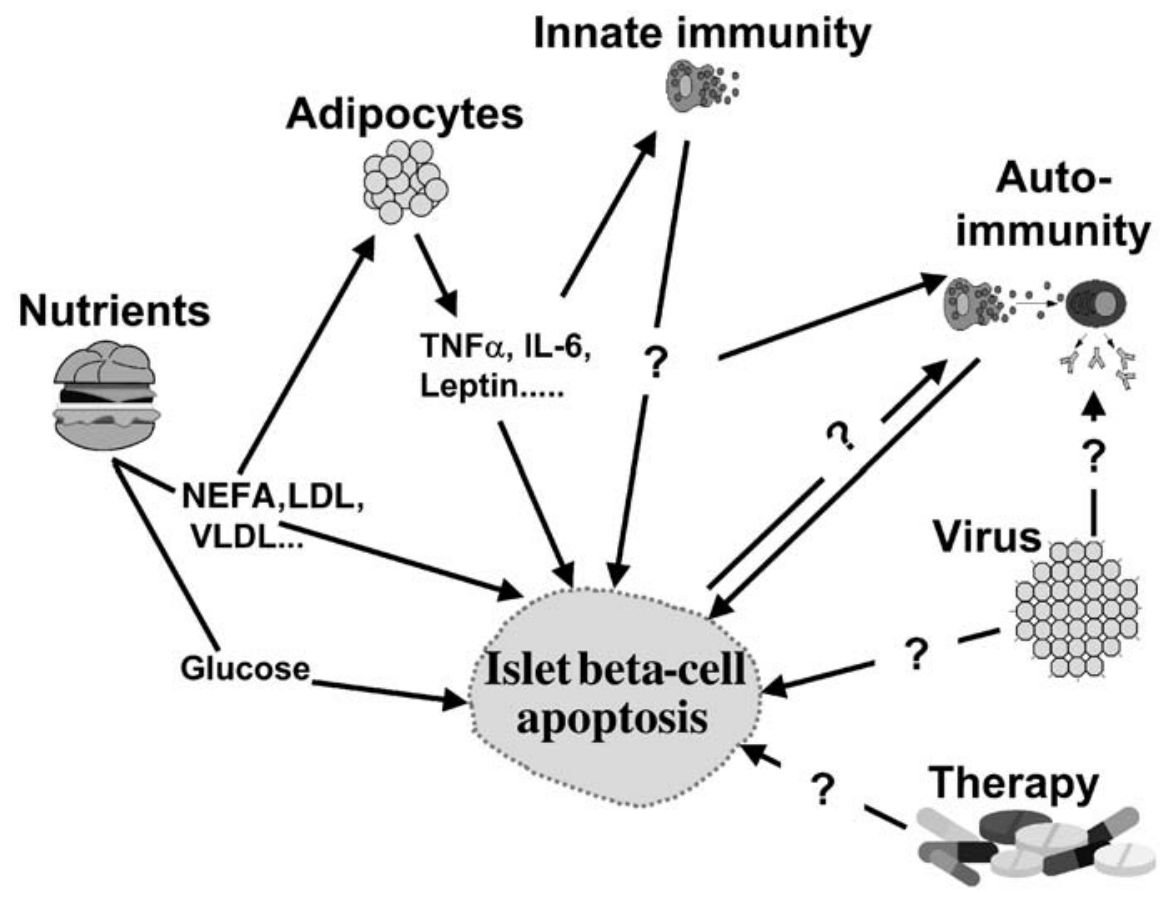

Fig. 1. Proposed model for the interplay between "aggressors" of the beta cell in the pathogenesis of diabetes. Factors possibly affecting beta-cell survival should be considered representative of the given pathway; the list is not intended to be comprehensive. Signalling pathways within the beta-cell leading to apoptosis are not included. Increased concentrations of glucose and lipids (NEFA, LDL, VLDL) are believed to have deleterious effects on beta cells. Lipids might affect the viability of beta cells directly or via obesity. Similarly, cytokines secreted by adipocytes (i.e. TNF $\alpha$, IL-6 and leptin) could act directly on beta cells or activate the innate immune system. In turn, innate immunity could favour an acquired immune response in genetically predisposed individuals. Additional factors precipitating beta-cell demise in diabetic patients include viruses and drugs. The aetiology of the particular diabetic condition and in turn the precise role and respective importance of each proapoptotic pathway will vary from one patient to the next

and dyslipidaemia on beta cells and possible molecular pathways (Fig. 1). Significant omissions include the possible pro-apoptotic roles of IAPP [20, 21, 22, $23]$ and inflammatory factors $[24,25,26]$.

From hyperglycaemia to beta-cell death. It is important to stress that glucose affects survival of human and rodent islets differently. This has led to a certain amount of confusion in the field. In brief, graded increases in glucose from 5.6 to $11.2 \mathrm{mmol} / \mathrm{l}$ and above induce apoptosis of human beta cells in vitro in a dose-related fashion [27, 28]. By contrast, studies on rat islets have shown that increasing glucose from a physiological concentration of 5.6 to $11.2 \mathrm{mmol} / \mathrm{l} \mathrm{de}$ creases apoptosis [29]. A further increase above $11.2 \mathrm{mmol} / \mathrm{l}$ has been shown to be either pro- or antiapoptotic depending on the study [29, 30]. However, islets from psammomys obesus, a gerbil, behave like human islets [31]. This small animal and humans both develop nutrient-dependent forms of diabetes, possibly reflecting the importance of glucose-mediated beta-cell loss in these two settings. In this context, it is important to consider the possible detrimental effect on beta-cell turnover of transient post-prandial glycaemic excursions early in the development of overt diabetes. This could perhaps underlie the decrease in beta-cell mass documented in patients with impaired fasting glucose, the earliest manifest stage of diabetes [8]. The situation is confounded by the fact that (in rodents) glucose can also stimulate proliferation [32] and neogenesis $[33,34]$ of beta cells: the relative impact on proliferation and apoptosis will thus dictate the outcome of decreased or increased beta-cell mass [19]. Furthermore, the mitogenic effects of glucose, at least in vitro, seem to be limited in time in human islets [28] but are long-lasting using rat islets. The mass of beta cells at any given time is thus the consequence of a complex algorithm reflecting glucose concentration, time, proliferation and apoptosis.

Given that glucose does induce apoptosis in beta cells what might be the mechanism? One clue may lie in the relative specificity of this toxicity towards the beta cell, but not other islet or most non-islet cell types. This cell is by design exquisitely sensitive to small changes in ambient glucose. When these changes are of short duration and in the physiological range as after a meal, they lead to insulin secretion. However, when of longer duration and more pronounced in magnitude, perhaps they are translated by the beta-cell glucose-sensing pathways into pro-apoptotic signals. One such signal might be increased ER-stress $[35,36$, 37]. The increased demand on beta cells in terms of insulin output leads to increased secretion as well as increased proinsulin biosynthesis to replenish beta- 
cell insulin stores [38]. The increase in proinsulin biosynthesis in turn causes an increased flux of protein through the RER. Flux through the RER of the beta cell is quite high compared with other cell types even under physiologic conditions and any further increase is expected to tilt the balance in favour of ER-stressinduced apoptosis. Chronic hyperglycaemia could also lead to long-term increases in cytosolic $\mathrm{Ca}^{++}$as opposed to the normal short-term increases arising from glucose-induced closure of ATP-dependent potassium channels $\left(\mathrm{K}_{\mathrm{ATP}}\right)$ ] that could in turn be pro-apoptotic [39]. High glucose also leads to the generation of reactive oxygen species (ROS) [40,41], believed to be particularly toxic to the beta cell. We have shown, using human islets, that high glucose in vitro activates an additional and unexpected apoptotic pathway involving beta-cell production of IL-1 $\beta$, activation of NFKB and Fas signalling [42]. This was confirmed in beta cells in sections of pancreata from patients with Type 2 diabetes [42]. This last pathway may turn out to be a unifying mechanism for beta-cell death in disease. The situation is complicated by the fact that as mentioned above, glucose (at least in vitro) has a dual effect on human beta-cell turnover, promoting proliferation in the short-term and apoptosis in the longer term [28]. We have suggested a common factor, FLIP providing a switching mechanism between these two opposing effects [43].

From dyslipidaemia to beta-cell death. Diabetes is associated with dyslipidaemia characterised by increased circulating concentrations of NEFA and changes in lipoprotein profiles. Both have been shown to be pro-apoptotic in the beta cell $[44,45]$. Intriguingly, saturated fatty acids such as palmitate are highly toxic to the beta cell whereas the mono-unsaturated fatty acids such as oleate are protective against both palmitate and glucose-induced apoptosis [46]. A similar balance between pro- and anti-apoptotic effects is found for lipoprotein action on beta-cell survival. VLDL and LDL are thus pro-apoptotic whereas HDL protects beta cells against these pro-apoptotic effects [45]. Fatty acid cytotoxicity is mediated by the ceramide-mitochondrial apoptotic pathway [47] whereas pro-apoptotic lipoproteins seem to act via c-Jun N-terminal kinase (JNK) [45]. Regardless of the importance of these pro-apoptotic pathways in some situations, dyslipidaemia is not common to all patients with Type 2 diabetes. Furthermore, toxicity of lipids towards beta cells may be influenced by or possibly dependent upon the prevailing glycaemia $[48,49]$.

The interplay and relative importance of beta-cell death caused by glucose or fatty acids/lipoproteins could thus vary from one patient to another. Additionally, other pathways may come into play. We have thus discovered that leptin, the protein hormone released by adipocytes, in addition to its established effect on insulin secretion $[50,51]$, induces apoptosis in human beta cells (Maedler et al; submitted for publication). This contradicts previous studies on rodent islets showing that leptin protects against NEFA-induced apoptosis [52]. Whether this reflects the use of rodent versus human islets or a truly selective protective effect remains to be investigated.

\section{Is there a common pathway linking reduced beta-cell mass and impaired beta-cell function?}

Clearly, loss of enough beta cells will lead to decreased insulin output from the pancreas. The interesting question is whether this is an "all-or-nothing" phenomenon, with a more or less direct relationship between beta-cell mass and function, or whether partial loss of beta-cell mass leads directly or indirectly to impaired secretion from the remaining cells. Before speculating on this, let us examine the known facts. In humans, before impaired glucose tolerance becomes apparent (the earliest manifestation of incipient diabetes) there may have been loss of as much as $~ 50 \%$ of beta-cell mass [8]. Surprisingly, as overt diabetes develops, further loss might be quite limited, amounting to no more than an additional $10 \%$ or so [8]. This certainly points to a secondary or parallel impairment of beta-cell function. Again in humans, hemi-pancreatectomy led to impaired beta-cell function [53] whereas in rats, partial pancreatectomy results in impaired insulin secretion resembling that encountered in Type 2 diabetes despite extensive regeneration of the remnant and only very modest increase in glycaemia at the time of study [54]. Taken together, one must conclude that decreased beta-cell mass can lead to impaired function but the mechanism is not apparent nor is it necessarily the sole answer.

Two mechanisms possibly account for such impaired beta-cell function consequent to decreased beta-cell mass: (i.) increased insulin demand on residual beta cells per se leads to changes in function (whether by ER-stress or other mechanisms), (ii.) hyperglycaemia consequent to decreased beta-cell mass drives the impairment in beta-cell function. Distinguishing between the two is complicated by the fact that decreasing beta-cell mass experimentally more often than not leads to a more or less prolonged period of hyperglycaemia $[55,56]$. Moreover, in many instances there is a compensatory regeneration of beta cells. Newly formed beta cells might not be as welldifferentiated as older, fully mature residents in the pancreas. Regardless, there is ample evidence from in vitro studies on islets (e.g. $[57,58])$ as well as in vivo by glucose infusion (e.g. [59]), that high glucose for extended periods of time leads to impaired beta-cell secretory behaviour. Although we agree with Gordon Weir et al. that "excessive glucose stimulation of a reduced beta-cell mass leads to functional abnormalities of the beta cell" [60], this is surely just one factor. 
Consequently we acknowledge that the initial events leading to the progressive increase in glycaemia seen in diabetes remain elusive. For example, a genetic component combined with excessive food intake may lead to clinically undetectable hyperglycaemic excursions that could have an effect at an early stage on beta-cell mass and/or function. Furthermore, glucose is just one factor influencing beta-cell mass. Finally, we stress the importance of the amplitude and duration of hyperglycaemia. It is thus known that shorter periods of increased glucose in humans in fact increase glucose sensitivity of insulin secretion [12, 62].

Whereas Type 2 diabetes in humans progresses over time, impaired beta-cell function appears to be reversible to a certain degree at all stages. Thus, if an individual with Type 2 diabetes, even with severe hyperglycaemia, is rendered euglycaemic by either pharmacological means or changes in life-style, beta-cell function, and in particular glucose-responsiveness, is restored $[63,64]$. This is particularly true at early stages of the disease where the limiting threshold for reversibility of decreased beta-cell mass has perhaps not been passed. Rendering an individual with Type 2 diabetes euglycaemic interrupts the vicious cycle linking decreased beta-cell function with hyperglycaemia. This might not only restore insulin secretory patterns but also allow for some restoration of beta-cell mass. Although there are many reasons for believing that this may occur in humans as in animal models of reduced beta-cell mass, it has never been documented directly and it will be difficult to do so as long as betacell mass cannot be measured non-invasively.

Unravelling the pathways leading to beta-cell death and impaired function may provide the basis for innovative therapy of Type 2 diabetes. This is particularly true when one considers the reversibility of impaired beta-cell function and possibly beta-cell mass discussed above. One example might prove to be longacting analogues of GLP-1 (or inhibitors of the enzyme DPP IV that degrades GLP-1) that will be in clinical use to enhance insulin-secretion but could have additional beneficial effects on beta-cell mass by stimulating proliferation and inhibiting apoptosis $[65$, 66]. Other examples for innovative therapy are $\mathrm{K}_{\mathrm{ATP}}$ channel openers. Treatment with diazoxide not only of patients with Type 1 but also with Type 2 diabetes, partially restores insulin secretion $[67,68,69]$. While this beneficial effect may be due to inducing beta-cell "rest", it could also reflect in part the anti-apoptotic effect of such drugs [29]. We believe that IL-1 $\beta$ secretion by the beta cell might be a common pathway linking hyperglycaemia to both impaired beta-cell function and beta-cell apoptosis. Blocking IL-1 $\beta$ signalling could thus be useful in treating Type 2 diabetes. Use of the natural soluble IL-1 receptor antagonist, IL-1Ra, might serve this purpose and we are currently investigating the effect of this protein in a clinical trial in Type 2 diabetes.

\section{Decreased beta-cell mass as a common denominator of Type 1 and Type 2 diabetes: clinical consequences and implications for the classification of diabetes}

Current classification of diabetes distinguishes between Type 1 and Type 2 [70]. Type 1 diabetes is defined by beta-cell destruction and subdivided into immune-mediated and idiopathic. For Type 2 diabetes, no mention is made of possible beta-cell loss. Emerging theories from basic scientists and diabetologists alike, are tending towards a unifying hypothesis of diabetes. While it is probable that genetic predisposition is an important feature in all forms of diabetes, advances in the field do not yet allow for useful classification on this basis and indeed do not exclude the broad spectrum of diabetic conditions we propose. So what is the evidence for blurring and overlapping diabetic conditions? Immunological phenomena (e.g. anti-islet cell antibodies) typically associated with Type 1 diabetes are encountered in 10 to $20 \%$ of socalled Type 2 diabetic patients, which led to a separate classification of these patients in a subtype named "LADA" (latent autoimmune diabetes of adults). We now have paediatricians studying islet cell autoimmunity in elderly diabetic patients [71]. Consider also the intriguing theory that obesity could underlie the observed increase in Type 1 diabetes [72], a causal correlation which has been recently confirmed in two independent studies [73, 74]. Meanwhile, clinical research has shown that changes in inflammatory cytokines are not limited to classic autoimmune-type diabetes but are increased in Type 2 diabetes [75, 76] and could indeed be useful as markers of risk for developing the disease [77]. That being said, this is also the case in obesity, in turn suggesting an intrinsic beta-cell defect of some kind that renders individuals susceptible to progressing from obesity to diabetes. Clearly the time-course and extent of loss of beta cells, in association with varying degrees of insulin resistance, will affect the clinical manifestations of the disease. Autoimmune destruction of the majority of beta cells in young individuals will lead to a rapid onset of the disease and if treatment is delayed, ketoacidosis will occur. This is rarely seen in adults with Type 1 diabetes, therefore referred to as suffering from LADA. The situation is, however, complicated by anecdotal reports from paediatricians describing the dynamics of the regression of beta-cell function in young Type 2 diabetic patients as much more rapid than in adult counterparts. If this observation holds true, there will be obvious therapeutic implications.

Observations from the basic scientist are equally illuminating. Apoptosis in the presence of cytokines including IL-1 $\beta$ may lead to an autoimmune response [78]. Moreover, both beta-cell apoptosis [8] and an increase of locally produced IL-1 $\beta$ [42] are observed in Type 2 diabetes. Furthermore, signalling networks pre- 
viously believed to be limited to islets of patients with Type 1 diabetes are detectable in islets from patients with Type 2 diabetes, e.g. Fas-FasL, IL-1 $\beta$ [28, 42, 43]. As mentioned above, apoptosis itself may induce an autoimmune response. Interestingly, apoptosis of beta cells precedes the emergence of insulitis in the NOD mouse [79] and lymphocyte infiltration is also observed consequent to apoptosis in islets of immune-competent $\mathrm{Pd} \mathrm{I}^{+/}$- mice [80]. Therefore beta-cell apoptosis, whether genetically programmed, or induced by a virus, IAPP, glucose or NEFA could prove to be a very early event. Depending on its magnitude and duration, secondary phenomena including insulitis may appear with different timing and severity, thus escaping notice. There has to our knowledge been no systematic attempt to detect insulitis in the pancreas of early-onset Type 2 diabetes. That being said, we do not ignore some morphological findings that appear to be specific to Type 2 diabetes, most specifically islet amyloid deposits, but they are not found in all cases of Type 2 diabetes just as insulitis has not been detected in all Type 1 cases examined. In both cases, we also recognise the importance of the timing of the events leading to such manifest morphological features; depending on this timing with respect to the age of the subject at autopsy and duration of the disease, these "morphological markers" may or may not be apparent. Certainly, it is not our intention to refute the existence of auto-immune diabetes. However, and as acknowledged by the Expert Committee on Diagnosis and Classification of Diabetes [70], beta-cell destruction in Type 1 diabetes can, in addition, arise by other mechanisms. Furthermore, as mentioned, immunological marker and inflammatory mediators are also detected in Type 2 diabetic patients. While we certainly do believe that autoimmune diabetes exists, the frontier between this form of diabetes and others is, to our mind, blurred.

Increasing evidence would now suggest that betacell death underlies most forms of diabetes. While the aetiology of beta-cell death may vary from one condition to the next, we reason that it will inevitably result in a state of insulin deficiency and impaired beta-cell function. We are not alone. According to his "Accelerator hypothesis", Wilkin states: "Clinically, there is little other than tempo to distinguish two types of diabetes" [81]. Therefore, we and others (e.g. [75, 81]) believe that the classification of diabetes should be revisited. The clinical definition of diabetes can continue to be that proposed by the American Diabetes Association and now generally accepted [70, 82]. In all instances, we now propose that individuals with these clinical features suffer from one of many conditions of relative or absolute insulin deficiency, that we propose calling simply "diabetes mellitus". The only subsidiary question is whether the patient has, in addition to insulin deficiency, insulin resistance. While an objective and ready index of insulin resistance does not exist in the absence of reliable and easily measurable surrogate markers, it may be sufficient in most cases to note whether the patient presents with obesity (and metabolic syndrome) and/or has a family history suggestive of insulin resistance. We propose the following subtypes in our classification: diabetes mellitus with or without insulin resistance, with or without autoantibodies.

So what is new? We already have just two major subtypes of diabetes: Types 1 and 2. Are we simply changing names? No. The fundamental difference is that our classification provides intrinsic guidelines for therapy since insulin resistance can be easily detected and indeed modulated. If present, insulin sensitivity should be targeted by lifestyle intervention, shown to be so effective in recent American, Chinese and European studies [83, 84, 85]. The earlier such intervention in the progression of the disease (i.e. patients with impaired glucose tolerance rather than overt diabetes) the better. This can be supplemented by insulin-sensitising agents. If these strategies fail or are insufficient, the next step could be to replace what is missing, i.e. insulin. We do recognise that insulin resistance is not peculiar to Type 2 diabetes. Indeed, patients with Type 1 diabetes can present with insulin resistance and/or obesity and this may be induced or exacerbated by intensive insulin therapy. The sub-classification "with or without autoantibodies", alas, has no impact on therapy today. Nevertheless, we include this as an incentive for further research leading towards targeted therapy and perhaps ultimately a means to prevent or slow down autoimmune destruction of beta cells.

What are the pitfalls? We do not underestimate the possibly negative effects of extensive use of insulin therapy: the menace of hypoglycaemia may be more of a concern than with other therapy. Moreover, it is generally accepted that patients, particularly the elderly, may be reluctant to treat themselves by injection. Insulin therapy does require greater support from health professionals and this could pose a problem. Finally, as we all recognise, exogenous insulin is not the perfect replacement for secretion from the beta cell. Many aspects of physiological insulin delivery are missing and this probably affects its efficacy. Certainly, we do not wish to promote irresponsible use of medication (whether insulin or other) when behavioural changes (moderate exercise and improved diet) can be efficacious. On the other hand, it is mandatory that patients with absolute insulin deficiency, as seen typically in younger lean individuals, receive insulin from the very beginning of the disease as currently practised by most diabetologists.

Given the rationale behind this approach to diabetes, namely that decreased beta-cell mass underlies all common forms of the disease, particular attention should be paid to the possible beta-cell toxic side-effects of any supplementary or alternative medication. For example, it is suggested from in vitro studies that sulphonylureas could have such effects both on rat 
[29] and human islets [86]. Whether these studies turn out to be of clinical relevance remains to be seen but they are in line with an important recent prospective study comparing insulin and sulphonylurea treatment of Type 2 diabetes. This study shows that treatment with insulin preserved beta-cell function more effectively than glibenclamide [87]. It remains to be established whether it is the beneficial effects per se of insulin or possible beta-cell toxicity of glibenclamide that account for this observation. While a deterioration of insulin secretion was seen in patients treated with sulphonylurea in the UKPDS, those treated with insulin were not evaluated in this regard [60]. This should not, however, detract from use of what have been shown to be effective drugs particularly in the elderly in whom any possible acceleration in the decrease of beta-cell mass could be of less clinical relevance. At the other extreme, prolonged use of any drug that could negatively affect beta-cell mass in young patients is clearly not indicated. It is too early to know whether the new generation of oral secretagogues such as the glinides will negatively or positively affect beta-cell turnover with prolonged use.

\section{Summary and conclusion}

We present evidence in support of the hypothesis that diabetes is a spectrum of clinical conditions all of which arise from relative or absolute insulin deficiency that is caused by decreased functional beta-cell mass. Hyperglycaemia is suggested to be a major, but not the only, driving force for beta-cell death. This does not, of course, exclude the existence of autoimmune diabetes and neither does it diminish its importance. The same goes for the genetic predisposition to diabetes. Current classification of diabetes is inadequate. We propose a new classification focused on decreased functional beta-cell mass and consequent insulin deficiency with two subtypes based on the presence or absence of insulin resistance and/or autoimmunity.

Acknowledgements. The authors are greatly indebted to Drs. E. Cerasi (Jerusalem), S.E. Kahn (Seattle) and G.C. Weir (Boston) for critical review of the manuscript and their numerous constructive suggestions. The authors' research is supported by the Swiss National Science Foundation Grants 3200-067049.0, 3200B0-101902/1 and PP00B-68874/1, by a grant from the European Foundation for the Study of Diabetes/Johnson \& Johnson Research Programme and by grant 4-1999-844 from the Juvenile Diabetes Research Foundation International.

\section{References}

1. Yalow RS, Berson SA (1960) Plasma insulin concentrations in nondiabetic and early diabetic subjects: determinations by a new sensitive immuno-assay technic. Diabetes 9:254-260
2. Karam JH, Grodsky G, Forsham PH (1963) Excessive insulin response to glucose in obese subjects as measured by immunochemical assay. Diabetes 12:197-204

3. Cerasi E, Luft R (1967) Insulin response to glucose infusion in diabetic and non-diabetic monozygotic twin pairs. Genetic control of insulin response? Acta Endocrinol (Copenh) 55:330-345

4. DeFronzo RA (1988) Lilly lecture 1987. The triumvirate: beta-cell, muscle, liver. A collusion responsible for NIDDM. Diabetes 37:667-687

5. Maclean N, Ogilvie RF (1955) Quantitative estimation of the pancreatic islet tissue in diabetic subjects. Diabetes 4:367-376

6. Kloppel G, Lohr M, Habich K, Oberholzer M, Heitz PU (1985) Islet pathology and the pathogenesis of type 1 and type 2 diabetes mellitus revisited. Surv Synth Pathol Res 4:110-125

7. Sakuraba H, Mizukami H, Yagihashi N, Wada R, Hanyu C, Yagihashi S (2002) Reduced beta-cell mass and expression of oxidative stress-related DNA damage in the islet of Japanese Type II diabetic patients. Diabetologia 45:85-96

8. Butler AE, Janson J, Bonner-Weir S, Ritzel R, Rizza RA, Butler PC (2003) Beta-cell deficit and increased beta-cell apoptosis in humans with Type 2 diabetes. Diabetes 52: 102-110

9. Yoon KH, Ko SH, Cho JH et al. (2003) Selective beta-cell loss and alpha-cell expansion in patients with Type 2 diabetes mellitus in Korea. J Clin Endocrinol Metab 88:23002308

10. Ward WK, LaCava EC, Paquette TL, Beard JC, Wallum BJ, Porte D (1987) Disproportionate elevation of immunoreactive proinsulin in type 2 (non-insulin-dependent) diabetes mellitus and in experimental insulin resistance. Diabetologia 30:698-702

11. Kahn SE, Halban PA (1997) Release of incompletely processed proinsulin is the cause of the disproportionate proinsulinemia of NIDDM. Diabetes 46:1725-1732

12. Ward WK, Beard JC, Halter JB, Pfeifer MA, Porte D, Jr. (1984) Pathophysiology of insulin secretion in non-insulindependent diabetes mellitus. Diabetes Care 7:491-502

13. Porksen N (2002) Early changes in beta-cell function and insulin pulsatility as predictors for type 2 diabetes. Diabetes Nutr Metab 15:9-14

14. Polonsky KS, Given BD, Hirsch LJ et al. (1988) Abnormal patterns of insulin secretion in non-insulin-dependent diabetes mellitus. N Engl J Med 318:1231-1239

15. Kahn SE (2003) The relative contributions of insulin resistance and beta-cell dysfunction to the pathophysiology of Type 2 diabetes. Diabetologia 46:3-19

16. Porksen N (2002) The in vivo regulation of pulsatile insulin secretion. Diabetologia 45:3-20

17. Ward GM, Walters JM, Aitken PM, Best JD, Alford FP (1990) Effects of prolonged pulsatile hyperinsulinemia in humans. Enhancement of insulin sensitivity. Diabetes 39: 501-507

18. Hellerstrom C (1984) The life story of the pancreatic B cell. Diabetologia 26:393-400

19. Bonner-Weir S (2000) Islet growth and development in the adult. J Mol Endocrinol 24:297-302

20. Verchere CB, D Alessio DA, Palmiter RD et al. (1996) Islet amyloid formation associated with hyperglycemia in transgenic mice with pancreatic beta cell expression of human islet amyloid polypeptide. Proc Natl Acad Sci USA 93:3492-3496

21. Kahn SE, Andrikopoulos S, Verchere CB (1999) Islet amyloid: a long-recognized but underappreciated pathological feature of type 2 diabetes. Diabetes 48:241-253 
22. Janson J, Soeller WC, Roche PC et al. (1996) Spontaneous diabetes mellitus in transgenic mice expressing human islet amyloid polypeptide. Proc Natl Acad Sci USA 93:7283-7288

23. Westermark P (1996) Islet pathology of non-insulin-dependent diabetes mellitus (NIDDM). Diabet Med 13:S46-S48

24. Eizirik DL, Mandrup-Poulsen T (2001) A choice of death - the signal-transduction of immune-mediated betacell apoptosis. Diabetologia 44:2115-2133

25. Corbett J, Serup P, Bonner Weir S, Nielsen JH (1997) Betacell ontogeny: growth and death. Diabetologia 40 [Suppl 3]:B27-B32

26. Donath MY, Storling J, Maedler K, Mandrup-Poulsen T (2003) Inflammatory mediators and islet beta-cell failure: a link between type 1 and type 2 diabetes. J Mol Med 81: 455-470

27. Federici M, Hribal M, Perego L et al. (2001) High glucose causes apoptosis in cultured human pancreatic islets of Langerhans: a potential role for regulation of specific $\mathrm{Bcl}$ family genes toward an apoptotic cell death program. Diabetes 50:1290-1301

28. Maedler K, Spinas GA, Lehmann R et al. (2001) Glucose induces beta-cell apoptosis via upregulation of the fas receptor in human islets. Diabetes 50:1683-1690

29. Efanova IB, Zaitsev SV, Zhivotovsky B et al. (1998) Glucose and tolbutamide induce apoptosis in pancreatic betacells. A process dependent on intracellular $\mathrm{Ca}^{2+}$ concentration. JBC 273:33501-33507

30. Hoorens A, Van de Casteele M, Kloppel G, Pipeleers D (1996) Glucose promotes survival of rat pancreatic beta cells by activating synthesis of proteins which suppress a constitutive apoptotic program. JCI 98:1568-1574

31. Donath MY, Gross DJ, Cerasi E, Kaiser N (1999) Hyperglycemia-induced beta-cell apoptosis in pancreatic islets of Psammomys obesus during development of diabetes. Diabetes 48:738-744

32. Chick WL, Like AA (1970) Studies in the diabetic mutant mouse. 3. Physiological factors associated with alterations in beta cell proliferation. Diabetologia 6:243-251

33. Lipsett M, Finegood DT (2002) Beta-cell neogenesis during prolonged hyperglycemia in rats. Diabetes 51:18341841

34. Paris M, Bernard-Kargar C, Berthault MF, Bouwens L, Ktorza A (2003) Specific and combined effects of insulin and glucose on functional pancreatic beta-cell mass in vivo in adult rats. Endocrinology 144:2717-2727

35. Harding HP, Ron D (2002) Endoplasmic reticulum stress and the development of diabetes: a review. Diabetes 51: S455-S461

36. Araki E, Oyadomari S, Mori M (2003) Endoplasmic reticulum stress and diabetes mellitus. Intern Med 42:7-14

37. Izumi $\mathrm{T}$, Yokota-Hashimoto $\mathrm{H}$, Zhao $\mathrm{S}$, Wang J, Halban PA, Takeuchi T (2003) Dominant negative pathogenesis by mutant proinsulin in the akita diabetic mouse. Diabetes 52: 409-416

38. Halban PA, Kahn SE, Lernmark A, Rhodes CJ (2001) Gene and cell-replacement therapy in the treatment of type 1 diabetes: how high must the standards be set? Diabetes 50: 2181-2191

39. Grill V, Bjorklund A (2001) Overstimulation and beta-cell function. Diabetes 50 [Suppl 1]:S122-124

40. Ihara Y, Toyokuni S, Uchida K et al. (1999) Hyperglycemia causes oxidative stress in pancreatic beta-cells of GK rats, a model of type 2 diabetes. Diabetes 48:927-932

41. Laybutt DR, Kaneto H, Hasenkamp W et al. (2002) Increased expression of antioxidant and antiapoptotic genes in islets that may contribute to [beta]-cell survival during chronic hyperglycemia. Diabetes 51:413-423
42. Maedler K, Sergeev P, Ris F et al. (2002) Glucose-induced beta cell production of IL-1beta contributes to glucotoxicity in human pancreatic islets. JCI 110:851-860

43. Maedler K, Fontana A, Ris F et al. (2002) FLIP switches Fas-mediated glucose signaling in human pancreatic beta cells from apoptosis to cell replication. Proc Natl Acad Sci USA 99:8236-8241

44. Shimabukuro M, Zhou YT, Levi M, Unger RH (1998) Fatty acid-induced beta cell apoptosis: a link between obesity and diabetes. Proc Natl Acad Sci USA 95:2498-2502

45. Roehrich ME, Mooser V, Lenain V et al. (2003) Insulin-secreting beta-cell dysfunction induced by human lipoproteins. JBC 278:18368-18375

46. Maedler K, Spinas GA, Dyntar D, Moritz W, Kaiser N, Donath MY (2001) Distinct effects of saturated and monounsaturated fatty acids on beta-cell turnover and function. Diabetes 50:69-76

47. Unger RH, Orci L (2002) Lipoapoptosis: its mechanism and its diseases. Biochim Biophys Acta 1585:202-212

48. Poitout V, Robertson RP (2002) Minireview: Secondary beta-Cell Failure in Type 2 Diabetes-A Convergence of Glucotoxicity and Lipotoxicity. Endocrinology 143:339-342

49. El-Assaad W, Buteau J, Peyot ML et al. (2003) Saturated fatty acids synergize with elevated glucose to cause pancreatic beta-cell death. Endocrinology 144:4154-4163

50. Roduit R, Thorens B (1997) Inhibition of glucose-induced insulin secretion by long-term preexposure of pancreatic islets to leptin. FEBS Lett 415:179-182

51. Kieffer TJ, Habener JF (2000) The adipoinsular axis: effects of leptin on pancreatic beta-cells. Am J Physiol Endocrinol Metab 278:E1-E14

52. Shimabukuro M, Wang MY, Zhou YT, Newgard CB, Unger RH (1998) Protection against lipoapoptosis of beta cells through leptin-dependent maintenance of Bcl-2 expression. Proc Natl Acad Sci USA 95:9558-9561

53. Kendall DM, Sutherland DE, Najarian JS, Goetz FC, Robertson RP (1990) Effects of hemipancreatectomy on insulin secretion and glucose tolerance in healthy humans. $\mathrm{N}$ Engl J Med 322:898-903

54. Bonner-Weir S, Trent DF, Weir GC (1983) Partial pancreatectomy in the rat and subsequent defect in glucose-induced insulin release. J Clin Invest 71:1544-1553

55. Weir GC, Leahy JL, Bonner-Weir S (1986) Experimental reduction of B-cell mass: implications for the pathogenesis of diabetes. Diabetes Metab Rev 2:125-161

56. Kjems LL, Kirby BM, Welsh EM et al. (2001) Decrease in beta-cell mass leads to impaired pulsatile insulin secretion, reduced postprandial hepatic insulin clearance, and relative hyperglucagonemia in the minipig. Diabetes 50:2001-2012

57. Kaiser N, Corcos AP, Sarel I, Cerasi E (1991) Monolayer culture of adult rat pancreatic islets on extracellular matrix: modulation of B-cell function by chronic exposure to high glucose. Endocrinology 129:2067-2076

58. Eizirik DL, Korbutt GS, Hellerstrom C (1992) Prolonged exposure of human pancreatic islets to high glucose concentrations in vitro impairs the beta-cell function. J Clin Invest 90:1263-1268

59. Leahy JL, Cooper HE, Deal DA, Weir GC (1986) Chronic hyperglycemia is associated with impaired glucose influence on insulin secretion. A study in normal rats using chronic in vivo glucose infusions. J Clin Invest 77:908-915

60. UK Prospective Diabetes Study Group (1995) UK prospective diabetes study 16 . Overview of 6 years' therapy of type II diabetes: a progressive disease. Diabetes 44:12491258

61. Leahy JL, Bonner-Weir S, Weir BC (1988) Minimal chronic hyperglycemia is a critical determinant of impaired insu- 
lin secretion after an incomplete pancreatectomy. J Clin Invest 81:1407-1414

62. Kahn SE, Bergman RN, Schwartz MW, Taborsky GJ Jr, Porte D Jr (1992) Short-term hyperglycemia and hyperinsulinemia improve insulin action but do not alter glucose action in normal humans. Am J Physiol 262:E518-523

63. Glaser B, Cerasi E (1999) Early intensive insulin treatment for induction of long-term glycaemic control in type 2 diabetes. Diabetes Obes Metab 1:67-74

64. Polyzogopoulou EV, Kalfarentzos F, Vagenakis AG, Alexandrides TK (2003) Restoration of euglycemia and normal acute insulin response to glucose in obese subjects with type 2 diabetes following bariatric surgery. Diabetes 52:1098-1103

65. Li Y, Hansotia T, Yusta B, Ris F, Halban PA, Drucker DJ (2003) Glucagon-like peptide-1 receptor signaling modulates beta cell apoptosis. JBC 278:471-478

66. Drucker DJ (2003) Glucagon-like peptides: regulators of cell proliferation, differentiation, and apoptosis. Mol Endocrinol 17:161-171

67. Greenwood RH, Mahler RF, Hales CN (1976) Improvement in insulin secretion in diabetes after diazoxide. Lancet $1: 444-447$

68. Bjork E, Berne C, Karlsson FA (1998) Induction of betacell rest in type 1 diabetes. Studies on the effects of octreotide and diazoxide. Diabetes Care 21:427-430

69. Guldstrand M, Grill V, Bjorklund A, Lins PE, Adamson U (2002) Improved beta cell function after short-term treatment with diazoxide in obese subjects with type 2 diabetes. Diabetes Metab 28:448-456

70. Report of the expert committee on the diagnosis and classification of diabetes mellitus (2003) Diabetes Care 26 [Suppl 1]:S5-S20

71. Pietropaolo M, Barinas-Mitchell E, Pietropaolo SL, Kuller LH, Trucco M (2000) Evidence of islet cell autoimmunity in elderly patients with type 2 diabetes. Diabetes 49:3238

72. Hypponen E, Virtanen SM, Kenward MG, Knip M, Akerblom HK (2000) Obesity, increased linear growth, and risk of type 1 diabetes in children. Diabetes Care 23:17551760

73. Kibirige M, Metcalf B, Renuka R, Wilkin TJ (2003) Testing the accelerator hypothesis: the relationship between body mass and age at diagnosis of type 1 diabetes. Diabetes Care 26:2865-2870

74. Libman IM, Pietropaolo M, Arslanian SA, LaPorte RE, Becker DJ (2003) Changing prevalence of overweight chil- dren and adolescents at onset of insulin-treated diabetes. Diabetes Care 26:2871-2875

75. Syed MA, Barinas-Mitchell E, Pietropaolo SL et al. (2002) Is type 2 diabetes a chronic inflammatory/autoimmune disease? Diabetes Nutr Metab 15:68-83.

76. Pickup JC, Crook MA (1998) Is type II diabetes mellitus a disease of the innate immune system? Diabetologia 41: 1241-1248

77. Spranger J, Kroke A, Mohlig M et al. (2003) Inflammatory cytokines and the risk to develop type 2 diabetes: results of the prospective population-based European Prospective Investigation into Cancer and Nutrition (EPIC)-Potsdam Study. Diabetes 52:812-817

78. Bellone M, Iezzi G, Rovere P et al. (1997) Processing of engulfed apoptotic bodies yields T cell epitopes. J Immunol 159:5391-5399

79. O'Brien BA, Harmon BV, Cameron DP, Allan DJ (1997) Apoptosis is the mode of beta-cell death responsible for the development of IDDM in the nonobese diabetic (NOD) mouse. Diabetes 46:750-757

80. Johnson JD, Ahmed NT, Luciani DS et al. (2003) Increased islet apoptosis in Pdx1(+/-) mice. JCI 111:1147-1160

81. Wilkin TJ (2001) The accelerator hypothesis: weight gain as the missing link between Type I and Type II diabetes. Diabetologia 44:914-922

82. Report of the Expert Committee on the Diagnosis and Classification of Diabetes Mellitus (1997) Diabetes Care 20:1183-1197

83. Diabetes Prevention Program (DPP) Research Group (2002) The Diabetes Prevention Program (DPP): description of lifestyle intervention. Diabetes Care 25:2165-2171

84. Tuomilehto J, Lindstrom J, Eriksson JG et al. (2001) Prevention of type 2 diabetes mellitus by changes in lifestyle among subjects with impaired glucose tolerance. N Engl J Med 344:1343-1350

85. Pan XR, Li GW, Hu YH et al. (1997) Effects of diet and exercise in preventing NIDDM in people with impaired glucose tolerance. The Da Qing IGT and Diabetes Study. Diabetes Care 20:537-544

86. Maedler K, Bucher P, Berney T, Spinas GA, Carr RD, Donath MY (2003) Differential effects of repaglinide, nateglinide and glibenclamide on apoptosis in human beta cells in vitro. Diabetologia 46 [Suppl 2]:A187 (Abstract)

87. Alvarsson M, Sundkvist G, Lager I et al. (2003) Beneficial effects of insulin versus sulphonylurea on insulin secretion and metabolic control in recently diagnosed type 2 diabetic patients. Diabetes Care 26:2231-2237 